\title{
Die positiewe invloed van esteties bevredigende geboue en'n goed versorgde skoolterrein op die skep van skoolklimaat
}

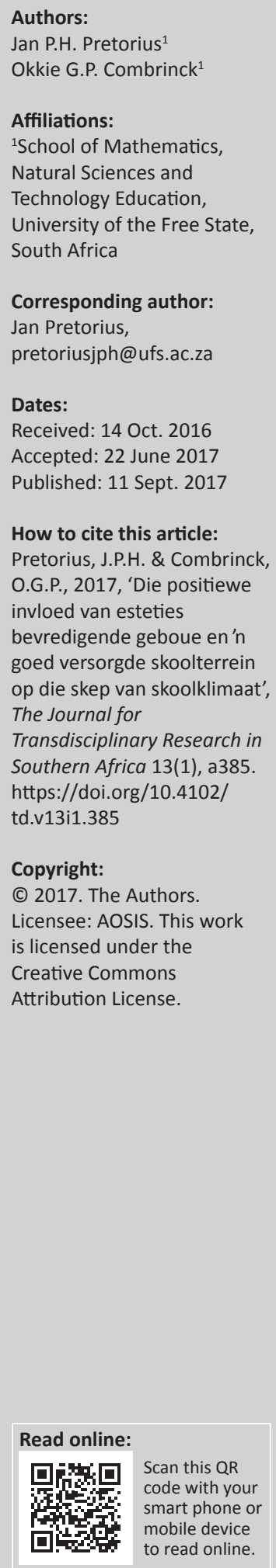

Authors:

Jan P.H. Pretorius ${ }^{1}$

Okkie G.P. Combrinck

Affiliations:

University of the Free State,

South Africa

Corresponding author:

Jan Pretorius,

Dates:

Received: 14 Oct. 2016

Accepted: 22 June 2017

How to cite this article:

Pretorius, J.P.H. \& Combrinck,

O.G.P., 2017, 'Die positiewe

van esteties

goed versorgde skoolterrein

op die skep van skoolklimaat,

Southern Africa 13(1), a385.

https://doi.org/10.4102/

Copyright:

Licensee: AOSIS. This work

is licensed under the

Creative Commons

mobile device

to read online.

\begin{abstract}
The positive influence of aesthetically pleasing buildings and well cared for school grounds on the creation of school climate. In this article the positive effect of beautiful school buildings and well-kept school grounds on a school's learners, teachers and parents is investigated. The methodology and theoretical foundation of Appreciative Inquiry were used to ask learners, educators and parents of Oranje Girls School in Bloemfontein, South Africa, about their experience of the influence the school's beautiful buildings and terrain exert on the education presented there. Six appreciative questions were put to the respondents. Four themes were identified from the participants' responses: the aesthetics of gardens and buildings; the influence of the history of the school; maintenance and buildings that tell something; and the influence of the buildings and grounds on education and interaction between learners, educators and parents. The themes and responses are embedded into, and compared to existing literature about the topic to demonstrate their relevance. It is argued that the performance of South African learners can be improved by renovating schools and by beautifying school grounds.
\end{abstract}

In hierdie artikel word die positiewe effek wat mooi skoolgeboue en 'n goed versorgde terrein op 'n skool se leerders, onderwysers en ouers het, ondersoek. Die metodologie en teoretiese grondslag van Waarderende Ondersoek is gebruik om leerders, onderwysers en ouers van Oranje Meisieskool in Bloemfontein uit te vra oor die invloed wat die skool se mooi terrein en geboue op hulle belewenis van die skool en die onderrig daar het. Ses waarderende vrae is aan respondente gestel. Vier temas is uit die deelnemers se response geïdentifiseer: die estetika van tuine en geboue; die invloed van die geskiedenis van die skool; onderhoud en geboue wat iets vertel; en die invloed van die geboue en terrein op onderrig en interaksie tussen leerders, leerkragte en ouers. Die temas en response word ingebed en vergelyk met bestaande literatuur oor die onderwerp om hulle geldigheid aan te toon. Daar word geargumenteer dat SuidAfrikaanse leerders se prestasies merkbaar verbeter kan word deur skole op te knap en skoolterreine te verfraai.

A teacher assigned to an old classroom stated that she almost cried when she saw her classroom for the first time, with holes in the walls, mismatched paint, and no bulletin boards. (Uline et al. 2010:615)

\section{Inleiding en teoretiese onderbou}

Reeds twintig jaar gelede het Earthman en Lemasters (1996:11) in 'n oorsig van studies wat die verband ondersoek tussen leerders se prestasies en die toestand van die skoolomgewing en -geboue, gerapporteer dat daar in vele van hierdie studies wel 'n verband gevind is. Volgens Uline en TschannenMoran $(2008: 56,59)$ en Uline et al. (2010:598) is daar sedertdien groeiende bewyse dat skole se geboue en terrein (infrastruktuur en fasiliteite) 'n direkte invloed het op die uitkomste wat leerders bereik. Garibaldi en Josia (2015:1592) argumenteer ook dat daar 'n verhouding is tussen die beboude omgewing, die sosiale en emosionele omstandighede vir leer en leerders se akademiese en ontwikkelingsuitkomste.

Só is verskille van tussen $5 \%$ en $17 \%$ gevind in die gemiddelde prestasies van leerders in funksionele geboue, vergeleke met leerders in skole met swak skoolgeboue (Uline \& TschannenMoran 2008:56). Die kwaliteit van skoolgeboue is ook verwant aan leerders se ingesteldheid en gedrag, insluitende vandalisme, afwesigheid, skorsings, dissiplinêre voorvalle, geweld en rook (Bernardi \& Kowaltowski 2006:158; Schneider 2002, aangehaal uit Uline \& Tschannen-Moran 2008:60). Tanner (2008:382) voorsien '... hard evidence that certain aspects of school design directly affect student outcomes'. 
Skoolgeboue is die leeromgewing waarin leerders en onderwysers hulle bevind en die gewaarwording van hierdie omgewing is belangrik vir produktiwiteit, gemak, veiligheid, onderrig en leer. Dit is goed gedokumenteer dat die fisieke eienskappe van skoolomgewings, soos beligting, geraas, binnenshuise lugkwaliteit en 'n aangename temperatuur, die ouderdom en die toestand van die geboue, leer beïnvloed (Li \& Sullivan 2016:149). Dieselfde twee navorsers het vasgestel dat leerders in klaskamers met 'n uitsig op groen gedeeltes beter aandag kon gee in die klas en gouer herstel het van stresvolle ervarings as hulle maats wat nie so 'n uitsig gehad het nie (Li \& Sullivan 2016:153-155). Daarom vorm skoolfasiliteite en -tuine ' $n$ integrale deel van die onderrigproses en die toestand daarvan affekteer alle betrokkenes. Hierdie fasiliteite moet deurlopend in stand gehou word ter wille van leerders sodat hulle hul potensiaal kan bereik en van onderwysers sodat hulle effektief kan onderrig. Verwaarloosde skoolgeboue en -terreine word gekoppel aan 'n klimaat van sosiale wanorde by skole.

Bloch (2009) beskryf die onbevredigende toestand van vele skoolgeboue en -terreine in Suid-Afrika:

The OECD [Organisasie vir Ekonomiese Samewerking en Ontwikkeling] commented on the number of schools made from mud, without lighting or facilities, and built by communities themselves, which collapse in the first rainfall or storms. Many schools do not have sports fields. Schools are often physically unappealing, damp and cold, or overheated in summer, and with few facilities like computer labs or libraries that might possibly draw children willingly out of their homes. (pp. 81-82)

Bloch (2009:82) dui verder aan dat:

- $17 \%$ van Suid-Afrikaanse skole geen toegang tot elektrisiteit het nie

- 19940 (79\%) skole nie biblioteekfasiliteite het nie

- $60 \%$ van sekondêre skole nie laboratoriumfasiliteite het nie

- $68 \%$ van skole geen rekenaars het nie

- $31 \%$ van skole van boorgate of reënwater afhanklik is

- van die 9461 skole met munisipale dienste, $6 \%$ afhanklik is van mobiele tenkwaens en $30 \%$ van gemeenskaplike staanpype

- $61 \%$ van skole met emmer- of putlatrines op geen manier van die riool ontslae kan raak nie.

Om hierdie probleme te vererger is skole soms die teiken van politieke onrus. So is meer as twintig skole in Vuwani in die Limpopo Provinsie, tydens oproer oor 'n munisipale grenskwessie, verbrand (Mahopo 2016: aanlyn) - sien Figuur 1.

Die omvang van die probleme hierbo dui daarop dat die oorgrote meerderheid van ons skole nie plekke is waar onderwysers, leerders of ouers graag hul tyd wil deurbring nie. Dit is nie net 'n Suid-Afrikaanse probleem nie; Figueroa, Lim en Lee (2016:20) het byvoorbeeld groot verskille in die verspreiding van hulpbronne tussen skole in verskillende provinsies van die Filippyne gevind; en uit

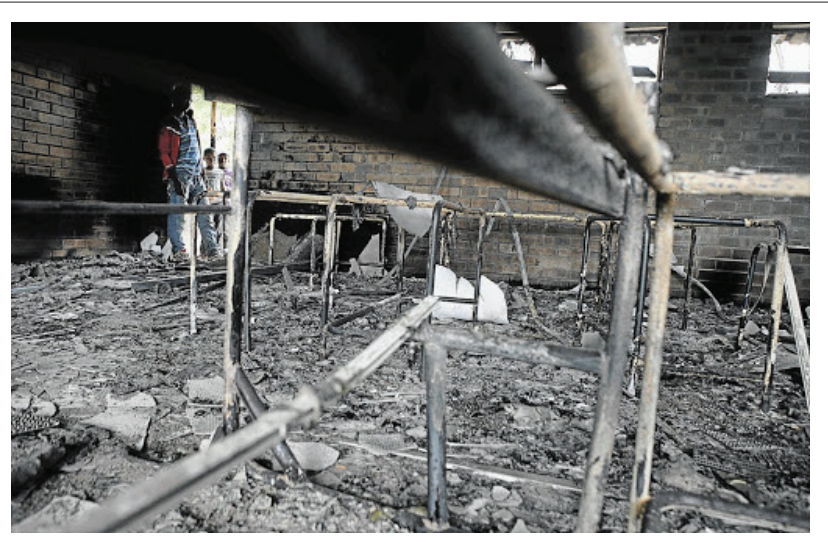

FIGUUR 1: Frank Mukhaswakule Primary was een van die dertien skole wat deur betogers in Vuwani, Limpopo aan die brand gesteek is.

die VSA rapporteer Uline en Tschannen-Moran (2008:55) dat skooldistrikte sukkel om tred te hou met stygende konstruksiekoste, toenemende leerdergetalle en die behoefte aan kleiner klasgroepe.

Die doel van hierdie Waarderende Ondersoek (verder $\mathrm{WO}$ ) is om die positiewe invloed van esteties bevredigende skoolgeboue en 'n goed versorgde terrein op die ouergemeenskap, personeel en leerders te verhelder en die invloed daarvan te illustreer. Ons hoop dit sal as aanmoediging dien vir die verantwoordelike persone om iets daadwerkliks te doen om skoolgeboue, -terreine en -geriewe tot voordeel van die opvoedingsproses te verbeter.

Bernardi en Kowaltowski (2006:156) reken dat die argitektuur van 'n skool as menslik beskryf kan word wanneer daar dekoratiewe elemente is en die plantegroei beplan en uitgelê is. Skole kan dus vermenslik word deur versiering en die aanlê van tuine. Ons wil aanvoer dat die teendeel ook waar is: lelike skole met min of geen tuine of plantegroei nie lei tot die verontmensliking van sodanige skole. Gifford (1976, soos aangehaal in Bernardi \& Kowaltowski 2006:156) argumenteer ook dat '[e]nvironmental numbness, or apathy towards the physical environment, causes a type of paralysis in the individual, where the user rarely exercises any attitude in relation to unpleasant situations'.

Wanneer 'n mens die vervalle toestand van die meerderheid Suid-Afrikaanse skole en die swak prestasie van sulke skole raaksien, wil dit voorkom of rolspelers - skoolhoofde, onderwysers, leerders, ouers en onderwysowerhede lamgelê word deur die omvang van die probleem. Dalk is 'n deel van die oplossing nie so ingewikkeld nie. Dalk sal die blote oprol van moue om skole te herstel en te verfraai verrassende resultate lewer.

\section{Teoretiese raamwerk van Waarderende Ondersoek}

Volgens Whitney en Trosten-Bloom (2010:2) moet die betekenis van die twee woorde waardering en ondersoek 
oorweeg word om te verstaan waaroor WO gaan. Waardering het te doen met erkentlikheid en dankbaarheid. Dit bring die beste in mense en die wêreld om ons na vore. Waardering behou dinge wat lewe, gesondheid, vitaliteit en uitnemendheid gee aan lewende menslike sisteme - soos skoolterreine en -gemeenskappe. Verder bevestig waardering die hoogtepunte, suksesse, bates en potensiaal van die verlede en hede. Waardering neem ook net soos 'n belegging toe in waarde. Die ondersoek verwys na die handeling van eksplorasie en ontdekking (Whitney \& Trosten-Bloom 2010:3). Die gees van ondersoek is die gees van leer. Dit impliseer 'n soeke na nuwe moontlikhede - terwyl die ondersoeker in 'n toestand is van nie weet nie, verwondering en gewilligheid om te leer. Dit beteken om vrae te vra, om te bestudeer, om te soek en om te delf.

Cooperrider, Whitney en Stavros (2008) formuleer die volgende klassieke definisie van die proses van WO:

Appreciative Inquiry [AI] is the cooperative co-evolutionary search for the best in people, their organizations, and the world around them. It involves the discovery of what gives 'life' to a living system when it is most effective, alive, and constructively capable in economic, ecological, and human terms. AI involves the art and practice of asking questions that strengthen a system's capacity to apprehend, anticipate, and heighten positive potential. The inquiry is mobilized through the crafting of the 'unconditional positive question', often involving hundreds or thousands of people. AI interventions focus on the speed of imagination and innovation instead of the negative, critical, and spiraling diagnoses commonly used in organizations. The discovery, dream, design, and destiny model links the energy of the positive core to changes never thought possible. (p. 3)

Omdat daar in die definisie melding gemaak word van 'n soeke na die beste in beide mense en organisasies, is hierdie artikel grootliks gefokus op mense se belewing van die beste in 'n skool se geboue en terrein, en die aanwending van 'n skool as organisasie se hulpbronne om 'n aangename onderrigomgewing vir onderwysers en leerders te skep.

Die positiewe beginsel as een van die grondliggende beginsels van WO (Cooperrider et al. 2008:7) word gebruik as teoretiese onderbou van ons studie. Kelm (2005:97) hou die woorde van William Arthur Ward voor om haar bespreking van die positiewe beginsel in te lui: 'When we seek to discover the best in others, we somehow bring out the best in ourselves'. Watkins, Mohr en Kelly (2011:74) sluit hierby aan: 'Momentum for change requires large amounts of positive affect and social bonding - things like hope, inspiration, and sheer joy in creating with one another'. Hierdie woorde belig die positiewe, afwagtende houding waarmee ons die waardering van die skool se geboue en terrein onderneem het. Reed (2007:74) noem dit 'a process of building on "what works" rather than what is going wrong or failing'.

So 'n benadering stem ooreen met wat Kelm (2005) aanbeveel, naamlik:

This principle suggests that positive emotion is essential for growth and optimal functioning. It creates energy and momentum for change, and provides important resources for short and long-term physical and mental health. (p. 97)

Positiewe emosies skep meer vreugde, maar dit is ook aan die kern van 'n produktiewe lewe (Kelm 2008:68): ‘We can build momentum toward greater joy by focusing on the positive core and paying attention to what really takes us upward'. Watkins et al. (2011) sluit weereens hierby aan:

Widespread inquiry into 'empowerment' or 'being the best organization in the field', will have a whole different long term sustainable impact for positive action than a study into 'low morale' or 'process breakdowns' done with the idea that those conditions can be cured. (p. 75)

Vanuit 'n navorsingsoogpunt kan die uitsluitlike of gedeeltelike fokus op die positiewe aspekte van 'n verskynsel probleme veroorsaak: kritici kan tereg daarop wys dat dit lei tot 'n selektiewe of onvolledige ondersoek (Reed 2007:75). Die idee dat navorsing ' $n$ volledige prentjie moet skets, is ' $n$ kragtige een en verleen ondersteuning aan aansprake dat navorsing nie bevooroordeeld mag wees nie. Sy wys egter ook daarop dat navorsing in die algemeen op die probleme van verskynsels fokus en dat WO, deur op die positiewe te fokus, op paradoksale wyse die idees van kritiese teorie toepas:

[i]f people are used to thinking of themselves as being unsuccessful, using [Appreciative Inquiry] to ask questions about achievements can be a valuable way of challenging those ideas, allowing people to think more critically (that is, to take a more comprehensive view) about what they do and the circumstances in which they do it. (Reed 2007:75-6)

Ons wil daarom nie beweer dat daar geen probleme bestaan wat betref die geboue en terrein van Oranje nie; inteendeel, ons sal pertinent daarop wys dat die beknoptheid en helling van die terrein van die skool problematies is. Vir die doeleindes van ons waardering verkies ons egter bloot om op die positiewe te fokus omdat ons paradoksaal wil glo dat dit 'n meer positiewe bydrae tot die oplossing van probleme sal lewer as wat probleemoplossing kan doen. Reed (2007:76) wys daarop dat alle navorsing in elk geval slegs gedeeltelik is deurdat dit altyd 'n fokus en area van belangstelling het en dat 'n fokus op die positiewe bloot bydra om die prentjie meer volledig te maak. Ons is oortuig daarvan dat ons studie 'n bydrae in hierdie opsig kan maak indien dit saam met ander studies met verskillende vrae en benaderings gelees word (Reed 2007:76).

\section{Konteks: motivering van keuse van Oranje Meisieskool}

Die Christelike en Nasionale Meisieskool Oranje in Bloemfontein bestaan uit drie susterskole op een terrein: die preprimêre skool, die primêre skool en die sekondêre skool. Elkeen van die skole het sy eie skoolhoof en beheerliggaam waarin ouers verteenwoordig word, maar daar is noue samewerking tussen die skoolhoofde en die onderskeie beheerliggame, wat gereeld saam vergader om gemeenskaplike sake te bespreek en gesamentlike projekte 
aan te pak en te koördineer. Elke skool het sy eie klaskamers, maar die skoolsaal en sportterreine word gedeel. Die skool word as gevallestudie gebruik om die positiewe invloed van geboue en terreine op die onderrigproses te waardeer.

Die skool is in 1907 gestig. Volgens die webblad (Oranjemeisies 2016) hou hulle tred met die moderne wêreld sonder om weg te doen met Christelike waardes, betekenisvolle tradisies en hoëgehalte-onderwys: hulle handhaaf 'n slim balans tussen werk en speel. Die gehalte van die buitemuurse aktiwiteite, soos sport en kultuur, is net so hoog soos die gehalte van akademiese onderrig. Enkele voorbeelde hieronder dien ter stawing.

In 2015, byvoorbeeld, is begin om tablette vir onderrig te gebruik en in 2016 begin leerders in grade 8-11 tablette in die plek van handboeke gebruik (Mentz 2016:4). Die skool behaal in hierdie jaar 'n 100\% slaagsyfer in die provinsiale matriekeindeksamen en word aangewys as die topskool in Wiskunde en Fisiese Wetenskap in die Vrystaat. Die skool behaal ook'n eerste plek in Afrikaans Huistaal en Engels Eerste Addisionele Taal in die provinsie. Oranje se tennisspan is aangewys as die SuidAfrikaanse verteenwoordiger by die Wêreldbyeenkoms in Katar, Indië. Een van die skool se tennisbane (sien Figuur 2) is vernoem na Amanda Coetzer, bekende Suid-Afrikaanse tennisspeler en oudleerling van die skool.

In die Bloemfonteinskole-hokkieliga het Oranje se A-span eerste en die B-span tweede geëindig. Oranje se A-span is vir die derde agtereenvolgende jaar as die topspan in Suid-Afrika gekroon. Die skool het 'n moderne, sintetiese astrobaan tot die beskikking van sy leerders. Die skool se swemspan het aan die toptien-meisieskole se Aquatics-byeenkoms in Durban deelgeneem en 'n derde plek behaal. Ook op atletiekgebied presteer die leerders uitstekend: Oranje is aangewys as die algehele wenner van die meisiesafdeling tydens die provinsiale interskolebyeenkoms in Bloemfontein.

Die redes waarom ons spesifiek hierdie skool gekies het, behoort duidelik te blyk uit die profiel van die skool hierbo. Dis

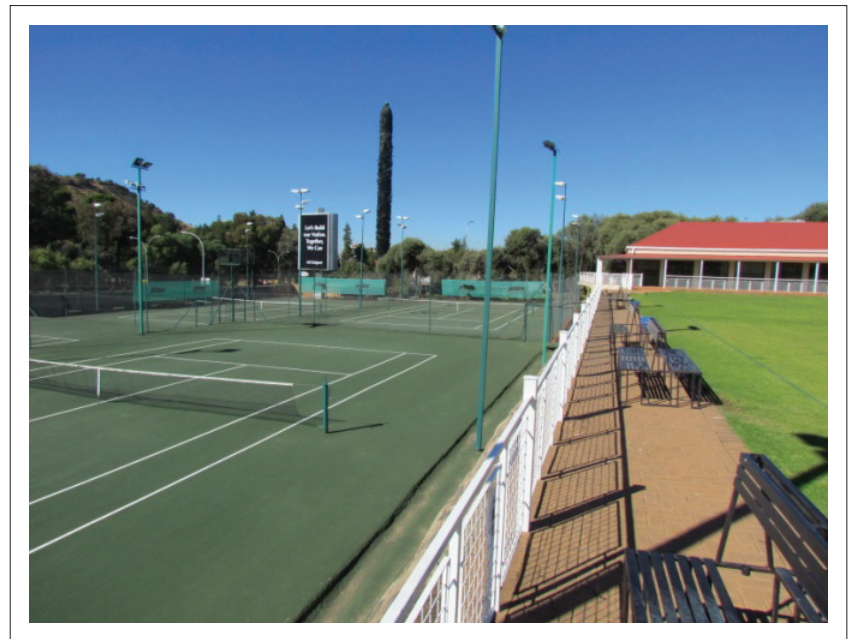

FIGUUR 2: Oranje se tennisbane en klubhuis. 'n uitstekende skool met uitstekende fasiliteite. Daar is egter 'n bykomende, ewe belangrike rede vir beide die keuse van die skool as die onderwerp van ons studie: om die onderliggende ongelykheid tussen ons land se topskole en skole in voorheen benadeelde gebiede, waarvoor die staat grootliks verantwoordelik is, uit te lig. Uline en Tschannen-Moran (2008) se wekroep is ook in die Suid-Afrikaanse konteks geldig:

In our efforts to ensure that all students have access to a rigorous curriculum and highly-qualified teachers, we must also face the condition of the physical environment within which teachers teach and learners learn. (p. 56)

Ons hoop om die onderliggende onregverdigheid (Uline et al. 2010:612) van die huidige situasie in die kollig te plaas.

\section{Navorsingsmetodologie en verloop van ondersoek}

Volgens Watkins et al. (2011:22) is WO in wese'n gesamentlike, hoogs deelnemende en sistemiese benadering tot die soeke na, die identifisering van, en die versterking van die 'lewegewende kragte' wat teenwoordig is wanneer ' $n$ sisteem optimaal in menslike, ekonomiese en organisasieterme funksioneer. Dit impliseer dat individue en organisasies op waarderende wyse ondersoek doen na daardie praktyke en faktore wat grondliggend is aan die suksesvolle funksionering van menslike sisteme.

In teenstelling met die paradigma onderliggend aan probleemoplossing - dat organisering en bestuur' $n$ probleem is wat opgelos moet word - word tydens WO aangeneem dat organisering 'n misterie is wat omhels moet word (Watkins et al. 2011:85). Tydens WO word die beste gewaardeer van wat in 'n organisasie gebeur; dit wat dalk kan wees of moontlik is, word gevisualiseer; dialoog word gevoer oor hoe en wat behoort te wees, waarna innoverende denke volg oor dit wat sal wees.

Volgens Whitney en Trosten-Bloom (2010:7) begin WO met die weldeurdagte identifisering van wat bestudeer gaan word: die bevestigende onderwerp. Hierdie onderwerp bepaal grootliks die agenda vir leer en verandering - wat ook verklaar waarom dit so belangrik is dat dit met groot omsigtigheid geformuleer sal word. Watkins et al. (2011:86) noem dit die 'Definiëringsfase' (sien Figuur 3) van die 5D-Model van WO. Tydens dié fase het ons bepaal dat die doel van ons navorsing tweeledig is: eerstens om 'n verkennende waardering, deur 'n steekproef rolspelers, te onderneem van die invloed wat 'n mooi skoolterrein en geboue op die belewenis van skoolonderrig het, en tweedens om die positiewe kern van die skool te bepaal. Ons wil daarop wys dat ons vir hierdie waardering slegs op die invloed van die buiteaansig van die geboue en op die terrein wil fokus; interne faktore soos byvoorbeeld die invloed van die getal leerders per klas, of die bestuurstyl van die skoolhoof val daarom buite ons fokus.

Die tweede fase word die Ontdekkingsfase genoem (Watkins et al. 2011:87 - sien Figuur 3; Whitney \& TrostenBloom 2010:7). 


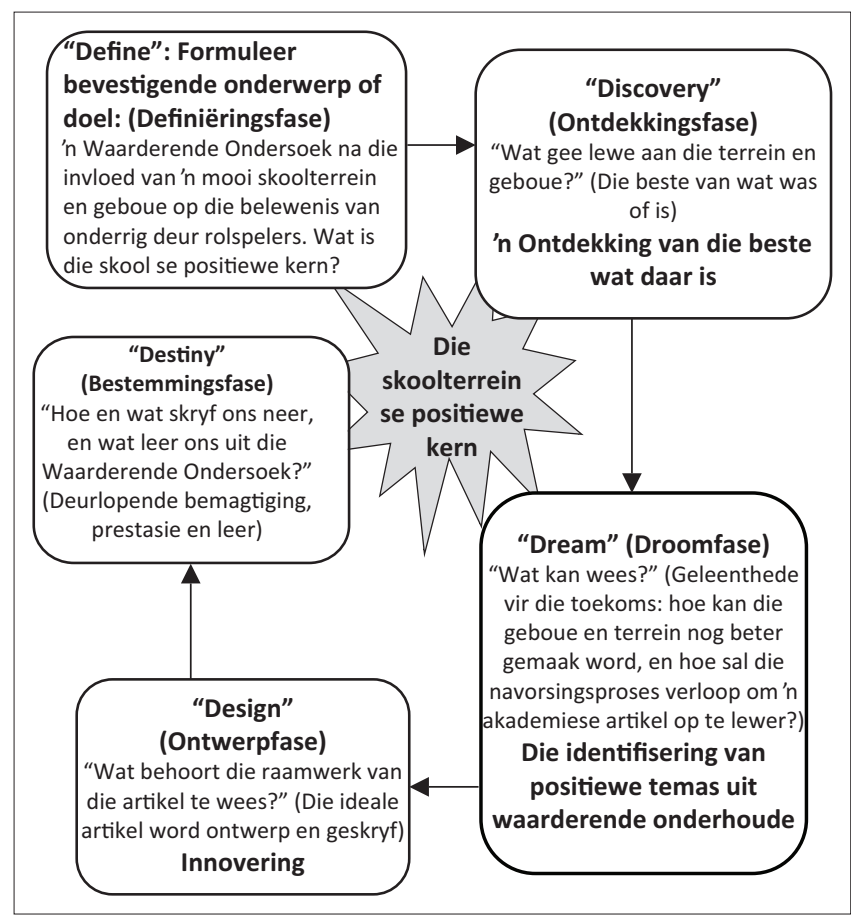

Bron: Die 5D-raamwerk as struktureel wetenskaplike onderbou vir die studie, soos aangepas uit Whitney en Trosten-Bloom (2010:6), asook Watkins et al. (2011:86)

FIGUUR 3: Die skoolterrein se positiewe kern.

Whitney en Trosten-Bloom (2010:7) beskryf dit as die koöperatiewe soeke om 'die beste van wat is en wat was' te verstaan. Volgens Watkins et al. (2011:87) moet 'die beste van wat is', gewaardeer word deur te fokus op tye van uitnemendheid - toe individue die organisasie (in hierdie waardering, spesifiek die geboue en terrein) as effektief en lewend ervaar het. Whitney en Trosten-Bloom (2010:7) stel voor dat dit tipies deur onderhoude van aangesig tot aangesig uitgevoer word, maar dit kan ook in fokusgroepe gedoen word.

Gebaseer op die eerste navorser se kennis van die spesifieke skool - sy eggenote is 'n onderwyseres verbonde aan die skool, en beide sy dogters was leerders daar - is besluit dat dit toepaslik is om 'n groep bestaande uit vier ouers, twee leerders en twee onderwyseresse deur die metode van doelgerigte of oordeelkundige steekproefneming (Babbie 2010:193) teidentifiseer.Hierdiemetodevansteekproefneming is ook gebruik deur Uline, Tschannen-Moran en Wolsey (2009:400) in hul ondersoek na die verband tussen die kwaliteit van twee skole in die VSA se fasiliteite en die skole se onderrigklimaat: 'The two schools, one urban and one rural, are selected purposefully for this study, maximizing learning from cases rich in information'.

Die volgende onvoorwaardelik positiewe vrae (Whitney \& Trosten-Bloom 2010:11) is tydens onderhoude onder vier oë deur die eerste navorser aan deelnemers gestel:

1. Wat is jou eerste of aangenaamste herinnering van die terrein van Oranje en die geboue?

2. Watter gebou is jou gunsteling, en waarom?

3. Watter invloed het die geboue en die terrein op die onderrig by die skool?
4. Wat is die een ding wat die geboue en die terrein beskryf, waarsonder dit net nie dieselfde sou wees nie?

5. As ons nou droom oor die geboue en die terrein, hoe sou jy dit oor tien jaar wou sien? Wat sou jy anders of beter wou sien?

6. Wat dink jy kan ander skole leer by Oranje omtrent hulle geboue en terrein?

Die eerste vier vrae is as deel van die Ontdekkingsfase aan die deelnemers gestel. Die laaste twee vrae word as deel van die Droomfase (sien Figuur 3) geag omdat die deelnemers tydens hierdie fase betrokke moet raak by gesprekke rakende die organisasie se roeping, sy potensiaal, asook die unieke bydrae wat dit tot die welstand van mense in die algemeen kan maak (Watkins et al. 2011:87-88). Volgens hierdie skrywers word verskeie stories oor die organisasie se geskiedenis gedeel en uitgelig sodat ' $n$ nuwe geskiedkundige narratief verskyn - wat weer lewe gee aan 'n positiewe toekoms. Die Droomfase is daarna voortgesit deur positiewe temas uit die onderhoude te identifiseer.

Tydens die Ontwerpfase is die raamwerk van die artikel gevisualiseer en geskryf. Watkins et al. (2011:88) noem hierdie raamwerk die sosiale argitektuur van die onderneming - 'n term wat uiters geskik is om die strukturele onderbou van ons navorsingsproses te omvat. Die voltooide artikel is aan die skoolhoof en bestuursliggaam van die skool voorgelê en toestemming is verleen vir die publikasie daarvan. Die artikel het sy finale bestemming bereik toe dit as deel van die Bestemmingsfase vir keuring aan ' $n$ akademiese vaktydskrif voorgelê en gepubliseer is.

\section{Uitkomste van die waarderende ondersoek}

Vier temas is uit die deelnemers se response geïdentifiseer: die estetika van tuine en geboue, die invloed van die geskiedenis van die skool, onderhoud en geboue wat iets vertel en laastens die invloed van die geboue en terrein op onderrig en interaksie tussen bewoners. Vervolgens gaan ons die temas een vir een ontleed en die response inbed in bestaande literatuur om sodoende die geldigheid daarvan te illustreer.

\section{Die estetika van tuine en geboue}

Estetika is ten nouste verbonde aan die ervaring van skoonheid en dit ontlok sterk emosies en gewaarwordings by mense (Uline et al. 2010:618). As sodanig kan die estetiese kwaliteite van 'n skool sterk gevoelens van behoort kweek, wat op sy beurt weer entoesiasme vir leer wek (Jarman, Webb \& Chan 2004, aangehaal uit Uline et al. 2010:618). Sodanige entoesiasme ontwikkel vanweë die emosionele reaksies op 'n skool se estetiese kwaliteite.

Uline et al. (2010:597-632) het die onderlinge wisselwerking tussen die kwaliteit van die fasiliteite van drie skole in een van Amerika se mid-Atlantiese state en dié skole se onderrigklimaat ondersoek. Hulle rapporteer dat estetika 
sterk figureer in die persepsies van die respondente in hul studie van skoolomgewings. By een van die deelnemende skole het 'n skoolhoof byvoorbeeld 'n dekoratiewe fontein laat oprig. Toe 'n groot boom doodgaan wat voorheen op hierdie plek gestaan het, wou die studente dit graag vervang met iets wat esteties bevredigend is. Ondanks pessimiste wat aangevoer het dat die leerders hul gemors daarin sou gooi, het die optimiste geseëvier en is die fontein vandag 'n fokuspunt in die gedagtes van die lede van die skoolgemeenskap (Uline et al. 2010:619). Die skoolhoof beskryf dit as ' $n$ vergaderplek vir die leerdergemeenskap en 'n plek vir stille refleksie.

In ons studie is daar ' $n$ soortgelyke fokuspunt in die gedagtewêreld van die skoolgemeenskap. Die Le Roux-huis (sien Figuur 4 en 5) is die gebou waarin die skool op 2 Augustus 1907 gestig is. Dit is vernoem na die eerste skoolhoof en is in 1976 tot ' $n$ nasionale monument verklaar. Tanner (2008:383, 394) kon statistiese bewyse vind dat die teenwoordigheid van 'n prominente verwysingspunt soos die Le Roux-huis 'n positiewe bydrae tot leerderprestasie maak.

Vir verskeie van die respondente in ons studie is dié gebou die mooiste op die terrein. Leerder B verwoord dit soos volg in haar antwoord op die vraag watter gebou haar gunsteling is:

Ek dink dis Le Roux-huis omdat ek so lank daar is. Dis regtig mooi. Die bloureën as jy kom om die sirkel daar. En die klomp klein kindertjies wat altyd daarom is. En dis lekker.

Die 'bloureën' waarna die leerder verwys, is 'n Wisteria sp. wat reeds in 1907 geplant is. Dit is saam met die gebou tot 'n nasionale monument verklaar.

Ook vir ouers B en C staan Le Roux-huis uit. Ouer C stel dit soos volg: 'Ek dink dit is die oudste gebou daar, so hy staan maar uit as jy hom sien. En my kinders moet daar bly, so hy moet vir my mooi wees'.

Leerder A verwys ook na die Voortrekkernooientjie (sien Figuur 5) voor die gebou:

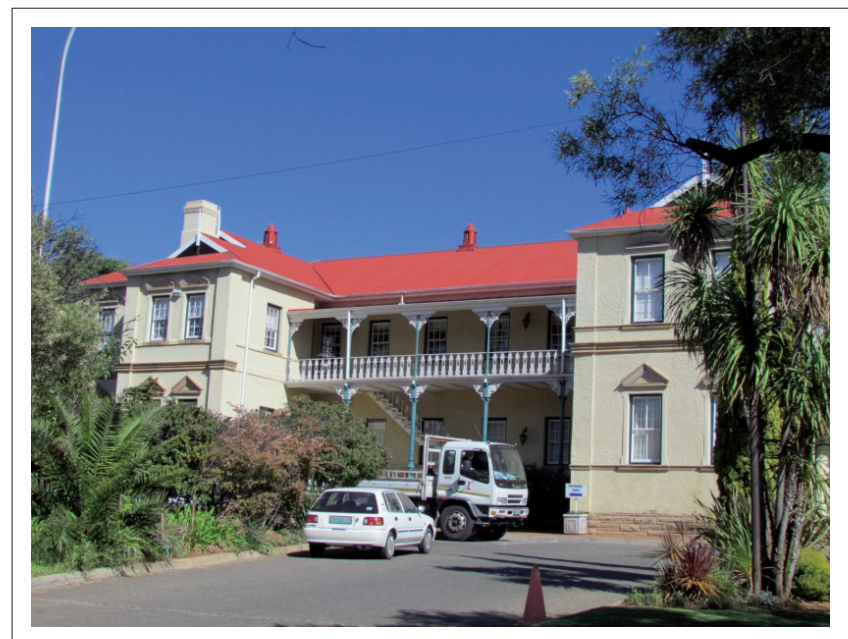

FIGUUR 4: Le Roux-huis, wat as koshuis en personeelkamer vir die primêre skool dien.
As mens inry by die skool, dan sien mens die mooi koshuis daar agter en die Voortrekkernooientjie. [...] Ek dink Le Roux-huis, dis mooi, die tipe huis daar is vir my baie mooi.

Hierdie beeldhouwerk is die handewerk van Laurika Postma, 'n oudleerder van die skool (Oranje Meisieskool, ongedateerd). Dit is in brons gegiet en op 19 Oktober 1940 onthul. Die idee agter die beeld is dat dit die leerders sal besiel om hul leuse, Vooruit, uit te leef. Die matrikulante het elke jaar op hulle laaste skooldag 'n seremonie by die beeld om sodoende afskeid te neem van die skool. Le Roux-huis en die Voortrekkernooientjie dra dus sterk daartoe by om 'n gevoel van iewers behoort by die leerders en skoolgemeenskap te vestig.

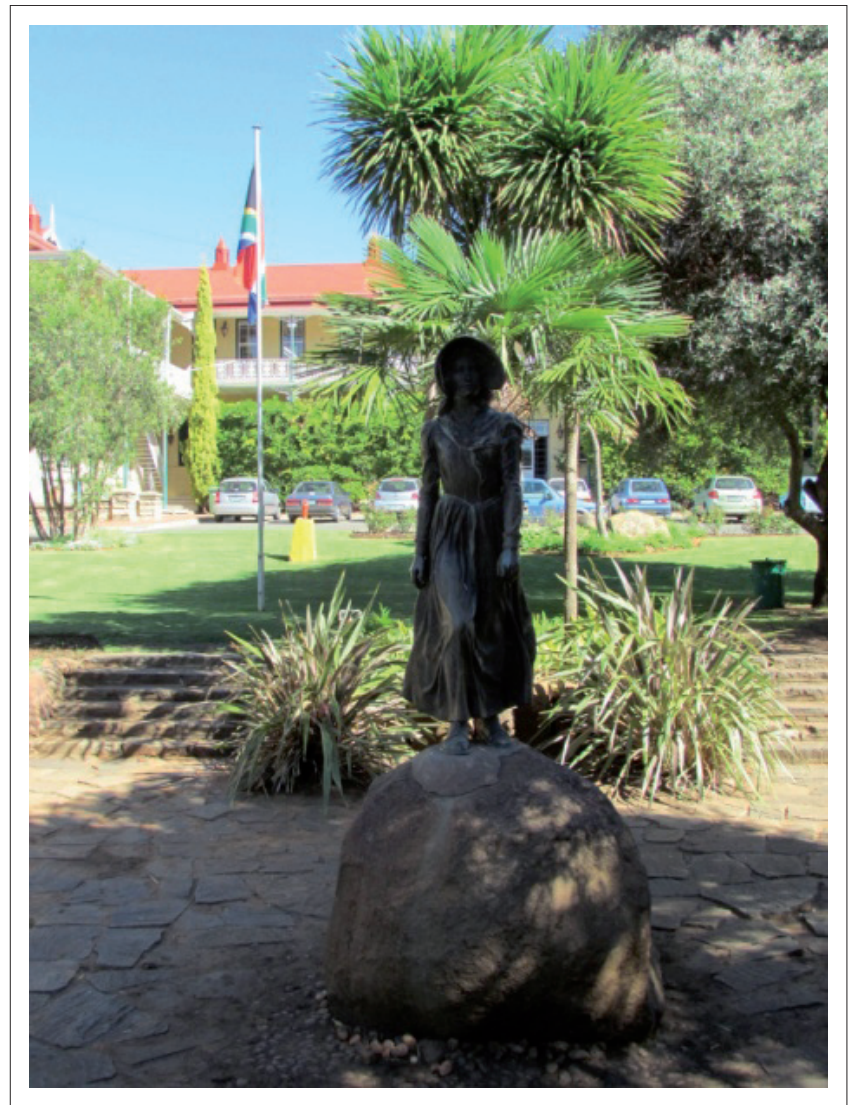

FIGUUR 5: Die Voortrekkernooientje met Le Roux-huis in die agtergrond.

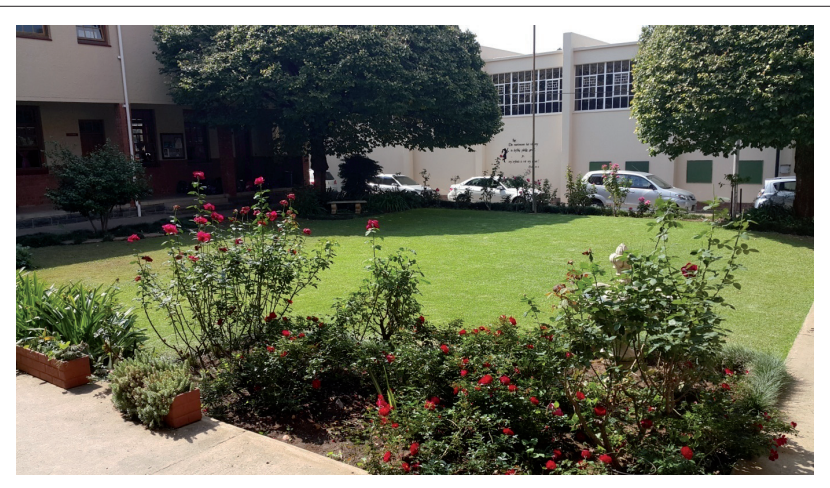

FIGUUR 6: 'En toe ek die oggend so uit my klas uitstap vir die eerste keer en die rooi rose was daar so voor my tuin, en hulle het so geblom en daai grasperke... dit was vir my die ongelooflikste oomblik by Oranje.' 
Uline et al. (2009:401) argumenteer dat die manier waarop 'n skoolgebou ontwerp, bestuur en onderhou word, 'n boodskap oordra omtrent die waarde wat geplaas word op opvoedkundige aktiwiteite wat daarin plaasvind. Al drie die skoolhoofde in die verdere studie van Uline et al. (2010) spreek ook hulle besorgdheid uit oor die boodskap wat hul fasiliteite aan leerders, ouers en die groter gemeenskap uitstuur. Een van die onderwysers - Onderwyser A - in ons studie deel klaarblyklik hierdie besorgdheid:

Ek ry verby die skole waar ek op skool was - baie dae - en ek sien hoe verslons en sleg lyk die tuine en geboue, dan dink ek by myself: dit is eintlik 'n refleksie van die mense wat binne is.

Uline en Tschannen-Moran (2008) bevestig hier die siening:

The manner in which a school building is designed, managed, and maintained sends a message to its occupants and community beyond, speaking volumes about the value placed on activities transpiring within its walls. (p. 67)

Die toestand van die skool se klaskamers is daarom 'n baie hoë prioriteit vir die skoolhoofde waarna hierbo verwys word. Oop ruimtes en groen ruimtes is ook hoog op hulle agenda. Een van hulle beskou die uitgestrekte teerbedekte oppervlakke van sy skool as esteties afskuwelik en beplan om binne drie of vier jaar grasperke en oop ruimtes tot die beskikking van sy leerders te stel omdat hulle desperaat is daaroor. Uline en Tschannen-Moran (2008:58) beklemtoon ook die behoefte aan positiewe buiteruimtes. Soos reeds genoem, het Li en Sullivan (2016:153-5) bevind dat leerders wat klaskamervensters met 'n uitsig op tuine het, beter aandag gee in die klas en dat hulle gouer herstel van stresvolle ervarings. Hul bevindings toon 'n kousale verband aan: groen uitsigte lewer beter aandagspanne en groter herstel van stres by leerders.

Onderwyser A beklemtoon die noodsaaklikheid van tuine en grasperke en deel ook die skoolhoof hierbo se weersin in siellose oppervlakke wat in hierdie geval met sementblaaie bedek is:

Nou staan jy buite jou klas en jy het niks om in vas te kyk nie. Jy kyk in sement vas, of jy kyk in bossies vas. Jou menswees, jou siel het skoonheid nodig en ek dink dís wat skole mis: hulle mis die punt. Hulle spaar die arbeid en belê in groot geboue en rugbyvelde en detail, terwyl 'n roosboompie en 'n grasperkie gaan dalk meer vir die kinders beteken. [...] Beton is nie tuin nie. Beton beteken 'ek werk minder', maar ek dink jy doen jou kinders skade. Want ek dink ' $n$ mens moet deur natuur en mooi goed omring word om te groei aan die binnekant.

Sy beskryf haar gewaarwordings toe sy die eerste keer by haar klas in Oranje uitstap:

En toe ek die oggend so uit my klas uitstap vir die eerste keer en die rooi rose was daar so voor my tuin, en hulle het so geblom en daai grasperke ... dit was vir my die ongelooflikste oomblik by Oranje [sien Figuur 6.] Daai van: 'Wow! Ek stap nie net uit op sement nie. Dis mooi hierso'. [...] Mense wat by ander skole skoolgehou het, wéét wat ons hier het. Dit definieer half die skool.

Vir ouer A is 'n ander skool wat hulle besoek het 'hard' weens al die sementblaaie:
Toe ons daar inry, dis 'n harde skool. Dit is, jy sien net geboue en sement. Daar is glad nie hierdie vriendelike tuine waar die kinders kan sit nie. Ek dink as kinders hier in die middae sit onder die bome (sien Figuur 7 en 8 ) gaan jy tog 'n gevoel kry van natuur wat jy nie kry by ander skole nie. Dis hard, sement. Dis 'n skool wat nie lekker is nie.

Uline et al. (2009) verwys in hierdie opsig na die kontraste tussen 'harde' en 'sagte' skoolomgewings:

... with hard environments referring to those physical attributes and spaces that are unresponsive and unyielding, compared to soft environments that are flexible and responsive, characterized by warm colors, soft furniture, and textured floor coverings. (pp. 402-403)

Hierdie kwaliteite het volgens hulle inderdaad 'n effek op die skoolomgewing.

\section{Die invloed van die geskiedenis van die skool}

Daar is in die vorige afdeling verwys na die tradisie dat die matrieks van Oranje op hulle laaste skooldag 'n seremonie by die Voortrekkernooientjie hou om sodoende afskeid te neem van die skool. Ouers woon dikwels hierdie seremonie by. Die skool hou ook jaarliks 'n kransleggingseremonie by die Vrouemonument in Bloemfontein, waarheen oudskoolhoofde en -leerders genooi word (sien Figuur 9). Dit is maar twee

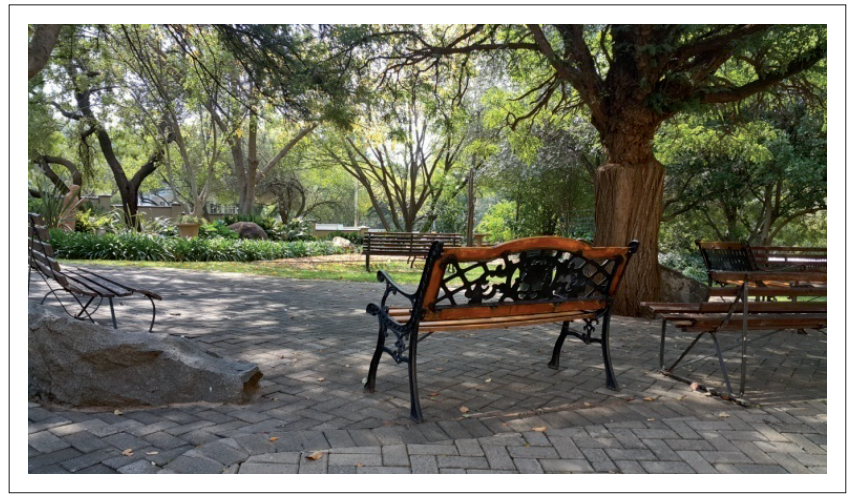

FIGUUR 7: Vriendelike tuine waar die kinders kan sit.

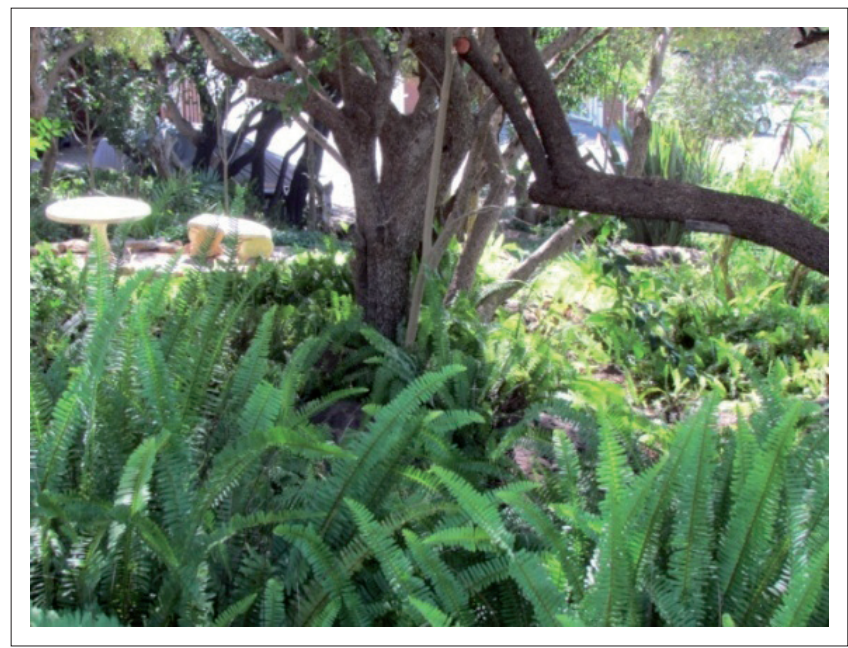

FIGUUR 8: Tuine waar die kinders kan sit. 


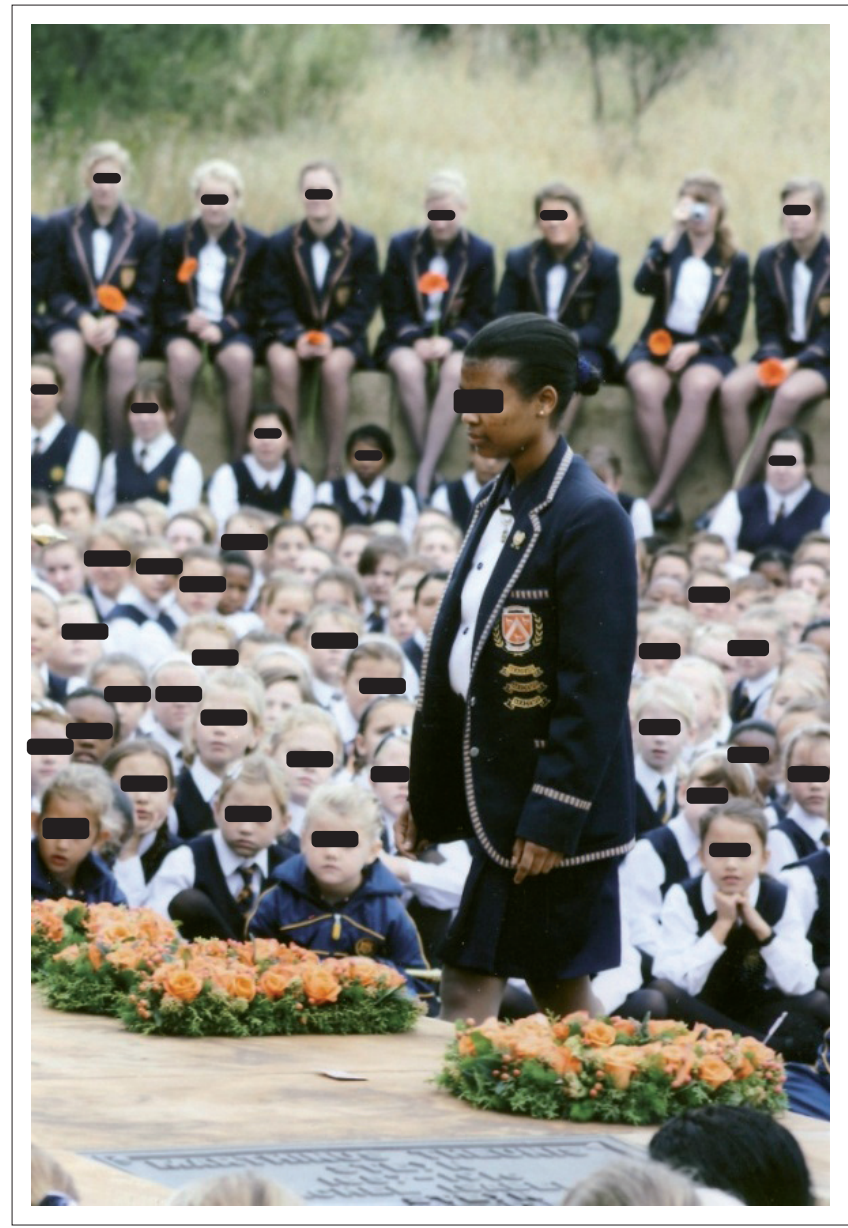

FIGUUR 9: Emme-Lancia Faro, vorige hoofmeisie van Oranje, lê 'n krans by die Vrouemonument.

voorbeelde van die manier waarop die skool se tradisies in stand gehou word.

Sodanige gemeenskapsbetrokkenheid skep 'n diep en volgehoue geskiedkundige verbintenis tussen huidige leerders en oudleerders (Uline et al. 2010:616). Die huidige leerders raak bewus van die gemeenskap van oudleerders en hulle prestasies en word dan dienooreenkomstig gemotiveer om hulle eie nalatenskap te vestig. So word respek vir die skool en sy terrein ook gekweek, wat weer tot volgehoue instandhouding en die netheid van die fasiliteite en tuine lei. Ouer A verwoord dit soos volg:

So, 'n wedersydse respek is daar, want die skool het respek vir die kinders: om hulle in ' $n$ mooi omgewing te laat skoolgaan, so dan verwag ek van my kind om respek te hê vir dit wat hier vir hulle gebied word.

Sy sê ook:

Hier is 'n omgee wat nie op ander plekke is nie. Hulle is trots op hulle skool. Hulle was nie van graad een af hierso nie, maar as ek sien hoe trots is my kinders op hierdie skool, verstom ek my.

Ouer $C$ bied 'n verklaring vir hierdie gevoel van trots op die skool: 'Nee ek dink daar is maar geskiedenis daaraan. Dis die storie daaraan. Dit skep tog 'n indruk by jou. Ek dink dis sy geskiedenis wat agter dit lế'.
Ouer C het ook waardering vir die instandhouding van die tradisies en geskiedenis van die skool:

Dis netjies. Dis iets om op trots te wees. Ek is bly hulle het nie net van waar die skool af kom vernuwe nie. Dat hulle dit gehou het. En dat die skool sy tradisie in stand hou. Jy kry dit nie meer nie. Hier is regtig ' $n$ tradisie wat ... ek dink dít is wat die kinders so opval, want onthou ons kinders word nie meer geleer van waar hulle vandaan kom nie. Maar ek dink die skool help hulle 'n bietjie daarmee. Onthou, kinders sukkel deesdae. Hulle weet nie meer waar hulle vandaan kom nie. [...] My kinders sou nooit Vrouemonument toe gegaan het [sien Figuur 9) as hulle nie in die skool was nie en daai deel van die geskiedenis ook geleer het nie. Dis vir my 'n geskiedkundige skool. Dis regtig 'n skool wat vir my voel asof hulle kan sê dit is 'n museum en dit bewaar. Dit is regtig ' $n$ skool vir die nageslag. Dis wonderlik.

\section{Onderhoud, geboue wat iets vertel en ouerbetrokkenheid}

Volgens Uline en Tschannen-Moran (2008:69) begin ons nou maar om te begryp hoe en wanneer 'n skool se fisieke strukture die vasgestelde doelwitte van onderrig en leer versterk. Ons begin verstaan waarom sekere ruimtes werk en ander nie werk nie. Terwyl beleidmakers soliede bewyse hiervoor soek, is navorsers besig om te verken hoe die gekompliseerde verwikkeldhede van die fisieke hoedanighede van 'n skoolgebou [en terrein] onderrig en leer beïnvloed:

Considering the degree to which school climate mediates this complicated interplay of factors may help to tell a compelling story about how human comfort, pleasing appearance, adequacy of space, functional furniture and equipment, a clean and orderly environment, and regular maintenance affects occupants' sense of wellbeing and thus their capacity to teach and learn (Uline \& Tschannen-Moran 2008:69).

Twee faktore hierbo het betrekking op ons studie en sal daarom verder ontleed word. Die eerste is die gereelde onderhoud van Oranje en sy fasiliteite as bydraende faktor om die skoolomgewing 'n aangename een te maak. Hiermee saam gaan ouerbetrokkenheid, waarsonder so 'n omvangryke onderhoudspoging feitlik onmoontlik sou wees. Edwards (1992), soos aangehaal uit Earthman en Lemasters (1996:8), het reeds bevind dat goeie ouerbetrokkenheid veroorsaak dat meer fondse vir die skool geïn word en dat sodanige skole se geboue in 'n beter toestand is as dié van skole met lae ouerbetrokkenheid. Uline en Tschannen-Moran (2008) argumenteer ewe sterk in hierdie verband:

A school with strong community engagement responds to the needs and concerns of parents and community members, and as a result should be able to marshal community support when needed. $[\ldots]$... the more schools were successful in keeping parents out, the lower student achievement was likely to be. (p. 61)

Onderwyser B verwys na die manier waarop die gemeenskap van Oranje in hierdie opsig groot bydraes maak:

En toe die oudste dogter in graad agt was, toe het hulle begin om vir elke graadkomitee ' $n$ tuin te gee. Toe het ons begin tuine maak en die geboue op te knap en al sulke goeters. En dan, ek is nou twaalf jaar hierso; in die twaalf jaar wat ek hier was, die geboue wat verbeter is. My eie klas het hulle verlede jaar alles 
uitgegooi en vir my oorgemaak en ek kon sê hoe ek dit graag wou hê. [...] Hulle probeer vir ons mooi maak, lekker maak om hier skool te hou, die lokale vir kinders lekker te maak, die nuutste tegnologie hier te hê, dit toeganklik te maak.

Hierdie noue betrokkenheid van ouers hou volgens Uline en Tschannen-Moran (2008) 'n groot voordeel in:

As communities actively engage with their schools, they come to understand the various needs associated with teaching and learning, including physical environments conducive to these primary school functions. (p. 61)

Ouers $\mathrm{A}$ en $\mathrm{M}$ het ook waardering vir die nougesette instandhouding van die terrein en geboue. Volgens ouer A:

... [is] dit mooi en hulle hou dit in stand. Die tuine is nie verwaarloos nie. Dit is netjies. Dis skoon. Ek dink dit dra by tot 'n lekker omgewing om in skool te gaan. [...] Ek weet hoeveel daar moet ingaan. Hoeveel tyd, hoeveel geld. Ek weet dit kós om dit in stand te hou. Miskien moet 'n ou meer, baie meer dankbaar wees oor waar jy is.

Ouer M sluit hierby aan:

Die feit dat dit, die nasionale gedenkwaardigheid - die koshuis, dat hulle dit erken en dat hulle dit bewaar, soos wat dit veronderstel is om bewaar te word: ek het baie waardering daarvoor... as ek nou dink hoeveel plekke gaan sommer net tot niet ....

Leerder A, op die vraag wat die één ding is wat die geboue en die terrein vir haar beskryf, waarsonder die plek net nie dieselfde sou wees nie, sonder die netheid uit:

Nee, ek dink die netheid. Ek dink dis baie netjies daarso. Die eerste indruk wat jy sien is netheid. Goed georganiseerd, goed bestuur. Instandhouding. Dit word in stand gehou. Kos ons ouers baie geld.

Leerder B beskryf op intuïtiewe wyse hoe die estetiese aard van die geboue haar in staat stel om positiewe konneksies met verskeie areas te ontwikkel en hoe die kleure warmte uitstraal:

Ek dink die geboue: dit is mooi. Dis nie asof dit ... dis nie afgeskeep nie. En die plek is mooi. So - ek's al gewoond aan dit vir twaalf jaar: Oranje, dat dit regtig al deel van jou geword het. En jy kweek op elke plek 'n herinnering. En die geboue is van so 'n aard en dis lekker kleure ook, want ek meen nie soos in negatiewe en koue kleure nie. Dis warm.

Earthman en Lemasters (1996:5) rapporteer hieromtrent dat die kleur van skoolgeboue inderdaad die prestasies van leerders beïnvloed. Tanner (2000) en Tanner en Lackney (2006), volgens Uline en Tschannen-Moran (2008:58), beklemtoon die noodsaak van '... pleasing or appropriate color, defined as age-and activity-appropriate color choices'.

Onderwyser A verwys na die grasie van die terrein en geboue:

Jy gaan nou dink dis 'n snaakse woord: 'graciousness'. Dis stylvol, dis grasieus. En tog is daar 'n dankbaarheid, want ek bedoel die Here is op die terrein. Ja, 'graciousness', want dis mooi en dis styl en dis grasie. Dit is tog wie ons probeer versinnebeeld. Ek voel 'n vrou moet stylvol wees. Sy moet grasie hê. En hou ouer jy word, ek dink omdat ek nou ouer word besef ek jy kan lelik word - óf jy kan altyd stylvol wees. En dis wat hierdie geboue is. Hier is jong kinders ook, maar dis nog steeds 'gracious' en dankbaarheid daaroor.

Onderwyser B verwoord die verhouding tussen geboue en inwoners selfs meer persoonlik en intiem: 'Die geboue en terrein maak sy arms vir jou oop en sê: "Hier is ek. Kom in"\#'. Die indruk dat daar subtiele boodskappe van 'n skool se geboue en terrein waarneembaar is vir die intuïtiewe persoon word bevestig deur Feldman en McPhee (2008:154) wanneer hulle verklaar dat 'everything speaks' in die skoolopset: '... every interaction, every person, every activity, every part of the physical environment, and every time interval makes a difference for learning'. Hier sien ons dus 'n verpersoonliking van die interaksies, geboue en terrein.

'n Interessante voorbeeld hiervan - maar aan die ander uiterste van die spektrum van skole in Suid-Afrika - word gevind in Manenburg op die Kaapse Vlakte, by die Red River Primêre Skool (sien Figuur 10), waar nuwe skoolgeboue ter waarde van R60 miljoen ingewy is (Jansen 2016:8). Die skool is geleë in ' $n$ area waar bendegeweld hoogty vier - '... reg in die middel van die kruisvuur tussen die Dixie Boys, die Hard Livings en die Clever Kids'. Die mure van die ou skoolgebou was vol koeëlgate - selfs in die skoolhoof se kantoor was daar twee (Jansen 2016:8). Die nuwe skoolhoof, mnr. Everett Poole bly nieteenstaande die klaarblyklik onoorkombare probleme soos armoede, maatskaplike ellende, drank- en dwelmmisbruik en oorvol klasse '... propvol optimisme: Die nuwe skoolgebou vra vir nuwe maniere van dinge doen.' [Ons kursivering]. 'Ons moet die grondgebied waarin ons lank as gyselaars aangehou is, terugneem' (Jansen 2016:8). Die artikelskrywer rapporteer dat Poole baie idees het vir Red River: kunsklasse, 'n atletiekbaan, handvaardighede en 'n sentrum vir volwasse leer.

Sal Poole slaag in sy planne? Hy kan dalk, want uit die literatuur in ons artikel blyk dit dat hy kragtige vennote in die nuwe skoolgeboue het - en dit kan 'n groot verskil maak as hy die algemene indruk wat die gemeenskap van die skool kry, ten goede kan verander. Uline en Tschannen-Moran (2008:59) noem die algemene indruk wat 'n leeromgewing skep '... a reflection of the personality of a place'. Uline et al. (2009:408) sluit hierby aan en reken dat die spesifieke persoonlikheid van die ruimtes binne 'n skool 'n gevoel van behoort by die betrokkenes kan skep - en dat daar dus 'n kollektiewe toewyding aan gedeelde leerdoelwitte is. Dit is waarom leerders duidelik gevormde identiteite as lede van die skoolgemeenskap het.

Die tweede relevante faktor waarna Uline et al. (2010) hierbo verwys, is voldoende ruimte: 'adequacy of space'. Weens die steil helling van die Oranje Meisieskool 


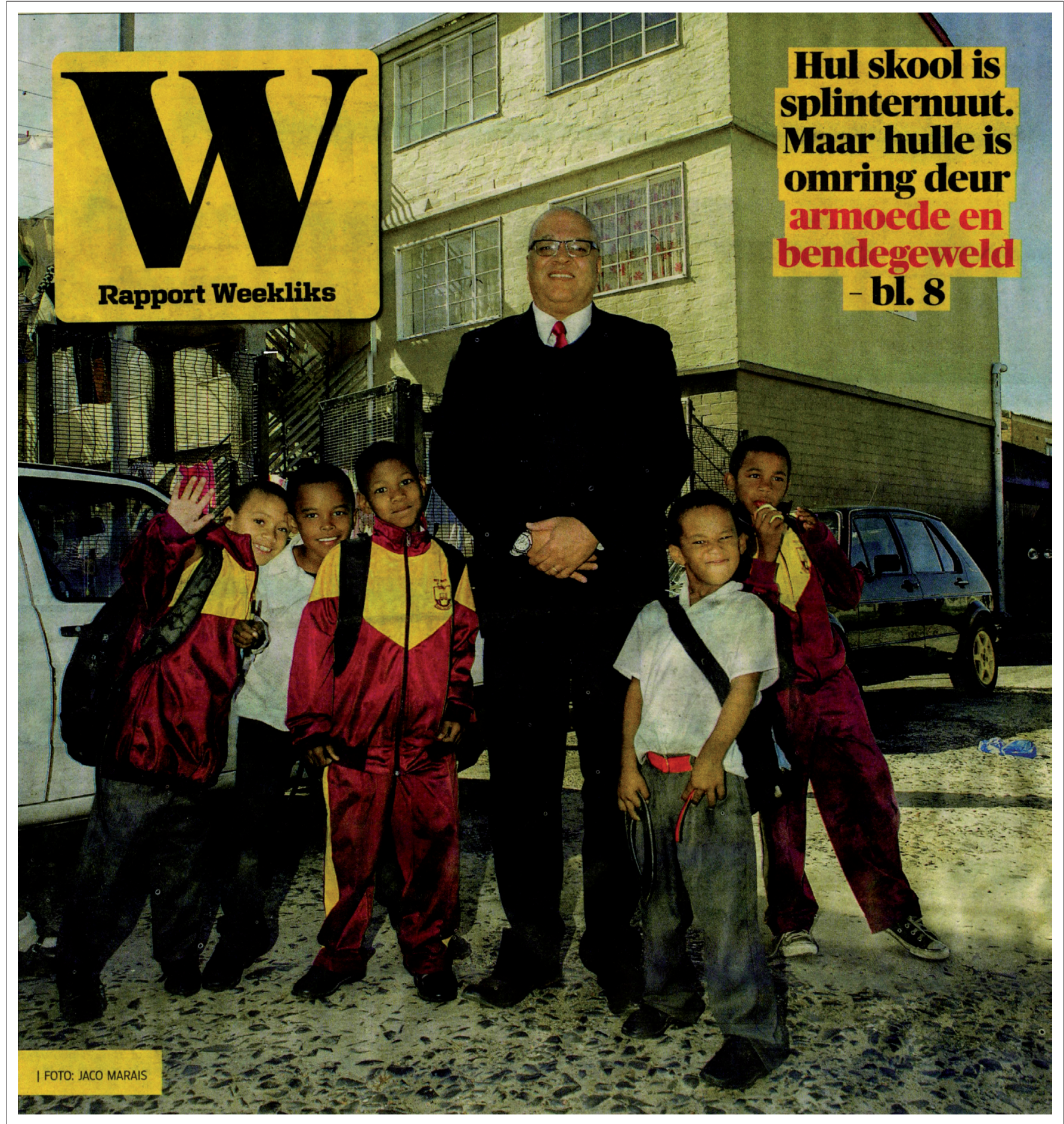

Bron: Rapport Weekliks, 2 Mei 2016

FIGUUR 10: Mnr. Everett Poole, skoolhoof van Red River Primêre Skool, saam met leerders voor een van die nuwe skoolgeboue wat teen R60 miljoen opgerig is.

se terrein en die ligging van die skool teen 'n koppie in 'n woongebied is daar nie veel ruimte vir uitbreiding nie en is parkering ook 'n probleem. Ouer B verwys spesifiek hierna:

Dis 'n baie mooi, rustige indruk wat jy kry as jy ingaan behalwe as jy moet parkeer. So, as jy nie moet parkeer nie, dan bly jy eintlik maar rustig. [...] Dis 'n moeilike terrein omdat dit so op en af is, jy weet. Dis van bo af, as jy vat hoe moeilik dit is eintlik, die vloei van parkering is baie moeilik om te reël.
Ouer B sluit hierby aan:

Ek dink dis tradisie, want dis so deel van die tradisie van ... en ek sien die parkeringprobleem is ook deel van die tradisie, want ek weet dis seker al dertig jaar wat dit so 'n gespook is met parkering.

Vir ouer C hou die relatiewe beknoptheid van die skoolterrein 'n groot voordeel in en daarom is sy meer positief daaroor:

Maar die positief, dink is, alles is bymekaar. Vir my as koshuisouer is daar nie ... my kind hoef nie die gronde te 
verlaat om aan aktiwiteite deel te neem wat die skool aanbied nie, hoef nie oor 'n straat te loop of so iets nie. So dis baie bymekaar. [...] Dit gaan vir ons als oor veiligheid omdat jy nie by jou kinders is nie.

\section{Invloed van die geboue en terrein op onderrig en interaksie tussen bewoners}

Uline en Tschannen-Moran (2008:68) argumenteer dat 'n kombinasie van gedeelde en persoonlike ruimtes waarin leerders en onderwysers werk, kan help om 'n ordelike en ernstige akademiese atmosfeer te voed. 'n Mooi en goed versorgde omgewing dra dus heelwat by tot die kwaliteit van die onderrig. In antwoord op die vraag oor watter area haar gunsteling is, reageer onderwyser A byvoorbeeld soos volg:

Daar waar my klas-area is, want dis vir my so mooi. Jy is in jou klas, jy is tussen jou vriendinne waarmee jy nou nie regtig kan kuier nie, maar jy is omring. Jy stap uit en dis mooi buite. Dis eintlik my gunsteling-area. Dis vir my lekker in my klas. Ek kan besig wees om 'n gedig te verduidelik, dan sal ek sê: 'Kyk, dís wat ek probeer sê!' Of ek sal dit kleur. Ek bedoel, jy kan dit nie by ander plekke doen nie. Of: 'How do you love them? Let me count the ways'. En dan sê ek: 'Kyk net daarso: hulle gee rose'.

Onderwyser B reken ook dat die geboue en terrein 'n positiewe invloed uitoefen op die onderrig, maar vir haar skep dit ook'n sekere gemeensaamheid tussen personeellede en help hulle om vrolik te wees:

Baie positief, weet jy, want dis lekker om in 'n mooi omgewing te werk. Dis lekker om skool toe te kom in die oggend en te kyk na die blomtuin. Dis lekker om te sien hoe netjies alles is. [...] En dan in die oggende as jy inkom in die personeelkamer, dan is almal vrolik en almal lag. En ek dink die atmosfeer en dinge, die geboue, ja die estetiese van die hele ding maak dit vir jou lekker.

Tanner (2008:383, 386, 394) kon 'n beduidende statistiese verband vind tussen die prestasies van leerders in leesbegrip, tale, wiskunde en wetenskap, en die teenwoordigheid van faktore wat buiteruimtes met bome, tuine, natuurlewe, heinings en gras insluit. Uline en Tschannen-Moran (2008) waarsku verder dat ons besondere aandag moet gee aan die maniere waarop verskillende ruimtes die daaglikse interaksies tussen en onder leerders, onderwysers en ouers aanmoedig. Vir leerder A gaan dit in hierdie verband sekerlik heel tipies - oor meer as die onderrig en meer oor speel as [self] onderrig, want sy onthou hoe die tuine (sien Figuur 11 en 12) hulle speelterrein was, maar ook hoe hulle die lesse wat hulle in die klas oor rommelstrooi geleer het, kon toepas:

En jou ma het jou nou maar baie sport en goed laat doen. Maar dan tog in die later middae het jy nou oop tyd gehad en dan het ons so in die tuine gespeel. Ons het huis-huis gespeel. Elke klip was iemand se bed [sien figuur 11]. Daar was 'n klip wat 'n rekenaar was [sien figuur 12]. Ons het daar sommer van die middagstudiekinders wat daarbo bietjie papiere gemors het, ons het die papiere verwerk in ons kombuis en later weggegooi. Nee, die tuine - hoe ons in hulle gespeel het en hoe jy eintlik ook so tuis gevoel het. (p. 68)

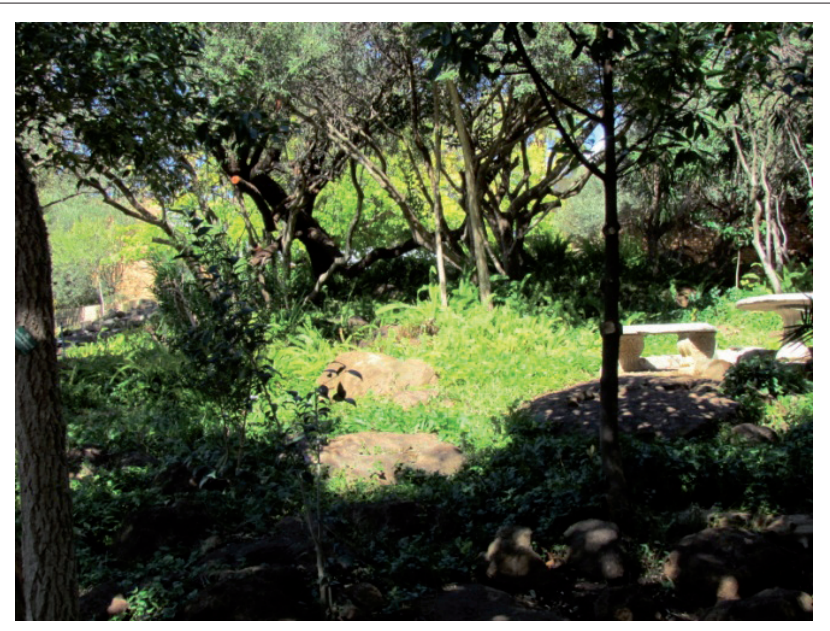

FIGUUR 11: 'Elke klip was iemand se bed.

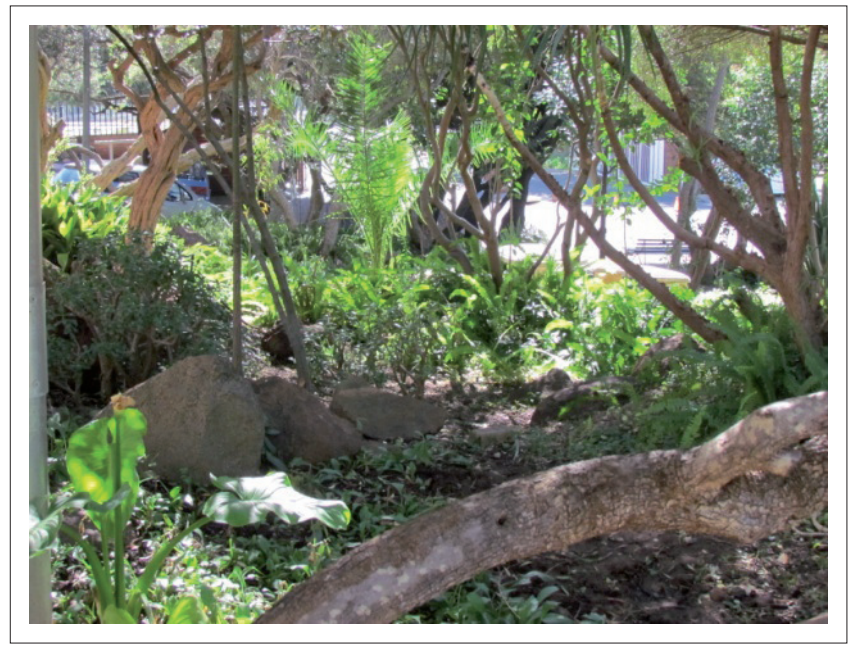

FIGUUR 12: 'Daar was'n klip wat'n rekenaar was.'

Uline (2000), aangehaal uit Uline en Tschannen-Moran (2008:68), reken dat ' $i$ i]f carefully conceived, the separate spaces of a school reinforce each other physically and aesthetically, creating rich environments where interpersonal relationships can flourish'. Uline en Tschannen-Moran (2008:68) se argumente sluit ten nouste aan by leerder A se beskrywing hierbo van hul speletjie en hoe die tuine hulle tuis laat voel het:

Design features that make for flexible and responsive environments create a sense of comfort and invite occupants to actively experience school life. When students feel comfortable to move within and beyond their individual classrooms, chances are they will engage more actively in their own, and each other's, learning. The particular personality of various spaces may encourage a sense of belonging and foster a collective commitment to share learning goals. (p. 68)

\section{Implikasies en tekortkoming van die studie}

Tydens hierdie Waarderende Ondersoek was die eerste gedeelte van ons tweeledige doel (sien Figuur 3) om die positiewe invloed van esteties bevredigende geboue en 'n goed versorgde skoolterrein op onderrig en die belewenis van 
'n skoolloopbaan te ondersoek. Deur die geïdentifiseerde temas uit die positiewe response van die deelnemers is aangetoon dat die invloed van die geboue en terrein op onderrig veelvlakkig, dinamies en kompleks is. Oranje Meisieskool presteer op al die vlakke wat van 'n skool verwag kan word: hul akademiese en sportprestasies is van die beste in die land en die skoolterrein en -geboue is esteties bevredigend en word goed onderhou en versorg. Dit lyk maklik om aan te neem dat dit 'n groot bydrae tot die skool se prestasies, positiewe onderrig en bevredigende leerervarings maak.

Wanneer 'n mens na Li en Sullivan (2016) se aanbevelings luister, klink dit byna of die gemeenskap, beplanners en bestuurders van Oranje insae daarin gehad het toe die geboue en terrein ontwerp is:

Architects should work to ensure that every classroom has views to green space. Landscape architects should consider the locations of classroom, cafeteria and hallway windows in the development of their campus designs [...] In addition to classroom views, views to green landscapes from hallways and the cafeteria seem particularly important. Providing views to green space in such areas will help students recover from mental fatigue and stress during their breaks and prepare students for their next class. (p. 155)

Bernardi en Kowaltowski (2006:156) argumenteer dat skoolgeboue gedeeltelik die leeromgewing van skole skep. Uline en Tschannen-Moran (2008:56) toon aan dat die interaksie tussen skoolgeboue en die kwaliteit van leeruitkomste ten minste gedeeltelik verklaar word deur die bemiddelende invloed van skoolklimaat. Hulle voer aan dat skoolklimaat ook 'n gedeeltelike verklaring is vir die negatiewe effek wat swak skoolgeboue op leer het. Vervalle, oorvol of ongerieflike skoolgeboue lei tot lae moreel en powere insette van beide onderwysers en leerders, tot verminderde gemeenskapsbetrokkenheid by 'n skool, en selfs tot mindere positiewe skoolleierskap. 'n Swak skoolklimaat kan moontlik 'n bydraende faktor wees tot swak prestasie indien 'n skool se fasiliteite onvoldoende is:

Our results revealed that when learning is taking place in inadequate facilities, there tends not to be as clear a focus on academics, and the learning environment is less likely to be perceived as orderly and serious. Where school buildings are shabby and inadequate, there is less likely to be the kind of community engagements that supports teaching and learning. Teacher attitudes and behaviors are related as well, as teachers are less likely to show enthusiasm for their jobs and to go the extra mile with students to support their learning when they teach in buildings they judge to be of poor quality. (Uline \& Tschannen-Moran 2008:66)

Uline et al. (2009) verwys na positiewe gevolge van goed versorgde skoolterreine op die klimaat van 'n skool:

The ongoing interaction between the design and reality of the built environment and the occupants of that environment helped to define the climate of the place. Reciprocally, the climate helped to shape interaction between and among people and between people and the built environment. These interactions further fashioned the personality of particular spaces at both Grant and Newcastle $^{1}$. (p. 409)

Hierdie interaksie lei selfs tot die versterking van bewoners se identiteit (Uline et al. 2009):

As building occupants shared in the creation of the environment, they revealed an individual and collective sense of themselves as members of their school community. In turn, the environment gave back, reinforcing self-identity and perhaps even changing members in some way. The result was a deeper sense of belonging within each setting. (p. 409)

Na aanleiding van bogenoemde wil ons graag die tweede gedeelte van ons tweeledige doel (sien Figuur 3) aanroer: om die positiewe kern van die skool te identifiseer. Ons kon dieselfde intieme verweefdheid en positiewe band tussen die respondente in ons studie en die terrein van Oranje, waarneem. Ons wil gevolglik die positiewe kern van Oranje ' $n$ aangename onderrigklimaat noem. Dit is vir ouers, onderwysers en leerders ' $n$ aangename omgewing om in te leer, te speel en saam te werk.

Ons studie was ten beste 'n verkennende kwalitatiewe ondersoek in samewerking met 'n geselekteerde groepie ouers, onderwysers en leerders. As sodanig sou dit onverantwoordelik wees om ons spesifieke bevindinge te wil veralgemeen. Desnieteenstaande - of dalk juis daarom - is genoeg insigte verwerf wat breër kwantitatiewe en kwalitatiewe ondersoeke regverdig. Dit lyk heel waarskynlik dat onderwysowerhede, deur bloot skoolterreine op te knap en in stand te hou, 'n wesenlike verbetering kan bewerkstellig in die bereiking van onderwysers en leerders se uitkomste.

Dit klink na iets wat nie onuitvoerbaar is nie. Om die waarheid te sê: dit klink na 'n opwindende vooruitsig - die herstel en mooimaak van ons land se verwaarloosde skoolterreine en afgeleefde skoolgeboue.

\section{Erkenning Mededingende belange}

Die outeurs verklaar dat hulle geen finansiële of persoonlike verbintenis het met enige party wat hulle nadelig of voordelig kon beïnvloed het in die skryf van hierdie artikel nie.

\section{Outeurs bydrae}

J.P.H.P. het die navorsing gedoen en die artikel geskryf. O.G.P.C. het die artikel hersien.

\section{Literatuurverwysings}

Babbie, E., 2010, The practice of social research, Cengage Learning, Wadsworth.

Bernardi, N. \& Kowaltowski, D.C.C.K., 2006, 'Environmental comfort in school buildings: A case study of awareness and participation of users', Environment and Behavior 38(2), 155-172. https://doi.org/10.1177/0013916505275307

Bloch, G., 2009, The toxic mix: What's wrong with South Africa's schools and how to fix it, Tafelberg, Kaapstad.

Cooperrider, D.L., Whitney, D. \& Stavros, J.M., 2008, Appreciative inquiry handbook, $2^{\text {nd }}$ edition, Crown Custom Publishers, Inc., Brunswick, $\mathrm{OH}$.

1.Die name van die twee skole in hul studie. 
Earthman, G. \& Lemasters, L., 1996, 'Review of research on the relationship between school buildings, student achievement, and student behavior', in Council of
Educational Facility Planners, International Annual Meeting, Tarpon Springs, FL. 8 October: $1-14$

Feldman, J. and McPhee, D., 2008, The science of learning and the art of teaching, Thomson Delmar Learning, Clifton Park, NY.

Figueroa, L.L., Lim, S. \& Lee, J., 2016, 'Spatial analysis to identify disparities in Philippine public school facilities', Regional Studies, Regional Science 3(1), 1-27. https://doi.org/10.1080/21681376.2015.1099465

Garibaldi, M. \& Josias, L., 2015, 'Designing schools to support socialization processes of students', Procedia Manufacturing 3, 1587-1594. https://doi.org/10.1016/j. of students', Procedia
promfg.2015.07.446

Jansen, J., 2016, 'Vervang dwelms net met liefde ...', Rapport Weekliks, 2 Mei, bl. 1, $8-9$.

Kelm, J.B., 2005, Appreciative living: The principles of appreciative inquiry in personal life, Venet Publishers, Wake Forest, NC.

Kelm, J.B., 2008, The joy of appreciative living: Your 28-day plan to greater happiness in 3 incredibly easy steps, Penguin, New York.

Li, D. \& Sullivan, W.C., 2016, 'Impact of school views on recovery from stress and mental fatigue', Landscape and Urban Planning 148, 149-158. https://doi. org/10.1016/j.landurbplan.2015.12.015

Mahopo, Z. 2016. Limpopo cops vow to 'arrest perpetrators' of school fire attacks Sunday Times. https://www.timeslive.co.za/news/south-africa/2016-05-05 limpopo-cops-vow-to-arrest-perpetrators-of-school-fire-attacks/
Mentz, L., 2016, 'Skole wat uitblink', Volksblad, 29 Januarie, bl. 4.

Oranjemeisies, 2016, Welkom by C\&N Meisieskool Oranje, besigtig op 29 April 2016, vanaf http://www.oranjemeisies.co.za

Oranje Meisieskool, s.a., Ons stap deur Oranje, oranje Meisieskool, Bloemfontein.

Reed, J., 2007, Appreciative inquiry: Research for change, Sage, Londen.

Tanner, C.K., 2008, 'Effects of school design on student outcomes', Journal of Educational Administration 47(3), 381-399. https://doi.org/10.1108/095782309 10955809

Uline, C. \& Tschannen-Moran, M., 2008, 'The walls speak: The interplay of quality facilities, school climate, and student achievement', Journal of Educational Administration 46(1), 55-73. https://doi.org/10.1108/09578230810849817

Uline, C.L., Tschannen-Moran, M. \& Wolsey, T.D., 2009, 'The walls will speak: The stories occupants tell', Journal of Educational Administration 47, 400-426. https:// doi.org/10.1108/09578230910955818

Uline, C.L., Wolsey, T.D., Tschannen-Moran, M. \& Lin, C.-D., 2010, 'Improving the physical and social environment of school: A question of equity', Journal of School Leadership 20, 597-632.

Watkins, J.M., Mohr, B. \& Kelly, R., 2011, Appreciative inquiry: Change at the speed of imagination, $2^{\text {nd }}$ edition, Pfeiffer, San Francisco, CA.

Whitney D. \& Trosten-Bloom, A., 2010, The power of appreciative inquiry: A practical guide to positive change, $2^{\text {nd }}$ edition, Berret-Koehler, San Francisco, CA. 